\title{
PUBLIC ADMINISTRATION OF ECONOMIC DEVELOPMENT IN THE CONTEXT OF THE INSTITUTIONAL THEORY
}

\author{
Valentina Dudchenko ${ }^{1}$ \\ National University "Odessa Law Academy", Ukraine \\ Konstantin Vitman ${ }^{2}$ \\ Centre for the Preparation of Masters of Public Service and Professional Judges, Ukraine
}

\begin{abstract}
One of the priorities of socio-economic reform in Ukraine is the modernization of the structure of the national economy and its growth. An effective structure of the economy, which will correspond to a socially oriented model of economic growth and will be based on the use of both the country's competitive advantages in the global division of labour and the economic benefits of cooperation, will guarantee the independence of any country and will be the key to its dynamic development. The development of economic theory is due to the emergence of fundamentally new ideas, sustainable accumulation of knowledge, intellectual and meaningful updating of established concepts and theories, the formation of new scientific schools. A new paradigm of economic theory should explain the real processes in real economies, which operate on the principles of complex systems of synergistic nature and the theory of nonlinear dynamics. There is a process of theoretical polystructuredness both of mainstream and heterodoxy. An important task is to form an interdisciplinary dialogue between economists and scientists, which stipulates the relevance of the research topic. The subject of the study is the theoretical and methodological foundations and approaches to state management of economic development in the context of the institutional theory. The purpose of the study is to determine the role and influence of public administration of the development of the economy in the context of institutional theory and to develop strategic goals of the state's innovation policy. Methodology. Directions of correlation of the system of economic development of the country and the potential of the state development with the historical preconditions for the emergence and development of the institutional doctrine of economic theory are investigated. Based on the revealed interrelations, the necessity of using instruments of institutionalism for studying the economic development system is substantiated. The state, in all available ways, should encourage economic actors to develop and implement innovations, thereby creating favourable conditions for innovative and technological development of production, saturation of the domestic market with highly competitive goods and services, which, in turn, will strengthen export potential, fill the budgets of all levels, increase incomes of business entities, reduce unemployment and improve working conditions, increase social security of the population, and also strengthen the positive image of public administration and local self-government bodies. That is, the socio-economic development of the country depends directly on the innovation-technological potential and on the efficiency of public administration in its development at all levels of the economy. Conclusions. The author generalizes the theoretical and methodological foundations of the country's development in the context of the institutional theory: the system of economic development of the state has a set of direct and indirect links with the historical background of the emergence and development of an institutional doctrine of economic theory; the revealed directions of correlation contribute to the formation of a scientific and methodological basis for further study of economic development and economic potential of a country (state) in the context of the institutional doctrine of economic theory in its relation to the public administration theory; the economic development of a country (state) depends on the institutional environment, in which it operates, and is both an object of its influence and a subject that determines its transformation. The author investigates the theoretical principles of state regulation of innovative and technological development of the country's economy. The existing strategies and programs of innovative development and innovation activity in Ukraine are explored. The state of innovation and technology of the national economy and the potential of key sectors of the economy in terms of innovative development are analysed.
\end{abstract}

Key words: institutional doctrine, public administration, stimulation mechanism, innovative and technological development, state regulation, innovation strategy.

JEL Classification: $\mathrm{H} 76, \mathrm{H} 83, \mathrm{H} 72, \mathrm{O} 31$

\footnotetext{
Corresponding author:

${ }^{1}$ Department of General Theoretical Jurisprudence, National University “Odessa Law Academy”.

E-mail: naukavvd@gmail.com

${ }^{2}$ Centre for the Preparation of Masters of Public Service and Professional Judges.

E-mail: knwittman@gmail.com
} 


\section{Introduction}

Issues of institutional architectonics have developed within the limits of modern scientific thought and have become the object of attention in most scientific studies, the content of which is associated with social dynamics and its management issues. The theoretical basis for the development of ideas of institutionalism can be considered works of T. Veblen, W. Hamilton, A. Hobson, J. Commons, and W. Mitchell, which laid the foundation for the formation of a modern institutional paradigm. The emergence of institutionalism is associated with the failure of the idea of economic liberalism and general equilibrium (harmony of interests and non-interference of the state in economic life) to effectively solve the problems of the cyclical economic development of the economy (economic and social instability). Traditionally, the main provisions of the institutional doctrine are used mainly within the limits of economic theory, which, of course, is quite a logical direction for scientific inquiry. At the same time, institutionalism as a direction of economic thought is used not only to "study the totality of socio-economic factors (institutions) in time but also to introduce social control over the economy" (Andriuschenko, 2009). Such a competence of institutionalism creates prerequisites for considering the possibility of using its toolkit in other scientific fields. For example, the issue of social control of a society in one form or another can be considered as one of the number of variants of manifestation of the subject of the scientific field of "public administration", namely, due to the interrelation of this category with the problem of "assessing social, economic, political, cultural, environmental consequences" of state-management activity (Bazylevych, Leonenko, Hrazhevska [ta in.], 2005). In addition, among the most important aspects of public administration, from a methodological point of view, along with others, "institutional (a set of institutions, state bodies, organizations involved in the implementation of management activities)" aspect is also distinguished (Kniazev, 2010), which creates preconditions for using the theoretical and methodological basis of institutionalism to find effective ways to use resources in order to achieve sustainable economic development of the state (Pokryshka, Zhalilo, Liapin [ta in.], 2010).

In today's conditions of development of the world economy, the economic role of the state depends on the level of participation in ensuring the conditions for the effective sustainable functioning of the national economy, which is based on the creation and use of innovative science-intensive products. Therefore, to create development conditions, the state forms goals and principles of its policy and its own priorities (Martynyuk, 2014).

The purpose of the study is to determine the role and influence of public administration in the development of the economy in the context of institutional theory and to develop strategic goals of the state's innovation policy.

\section{Methodology}

Recently, the attention of domestic and foreign scientific thought to the problems of institutionalism has increased, which has led to the formation of separate scientific groups, centres of institutional research, specialized departments, etc. For example, at the Institute for Economics and Forecasting of the National Academy of Sciences of Ukraine, around the topic "Institutional Architectonics and Dynamics of Economic Transformations", a group of scientists led by A. Hritsenko was formed, whose studies led to a new direction in scientific research within institutionalism. These researches are connected with the development of such an institutional model of social relations, the essence of which is natural in relation to the basic system of value orientations of citizens and their cultural and mental peculiarities of development. Among the powerful scientific schools in Russia, the issues of which include certain aspects of the institutional doctrine, it is necessary to highlight the Volgograd Scientific School of Evolutionary and Regional Economics, headed by its founder O. V. Inshakov, a team of scientists of the Institute of Economics of the Russian Academy of Sciences, centred within the scientific direction "Institutes of Modern Economics and Innovative Development" led by A. E. Gordetskyi, a group of researchers from the Institute for Institutional Studies at the National Research University - Higher School of Economics, led by Ya. I. Kuzmin, and so on.

Among the scholars, whose scientific interests included institutionalism issues, are V. V. Volchik, D. P. Gavra, V. V. Dementieva, V. V. Dementiev, S. G. Kirdina, O. V. Kochetkova, P. M. Nureiev, V. L. Tambovtsev, V. M. Tarasevych. Despite the strong dynamics of the development of institutional doctrine, there are many promising areas of research, the general classification of which can be given by the main branches of socio-economic knowledge: economics, politology, sociology, public administration, law, etc. Each of these areas has its own range of scientific competence within the scope of institutionalism, the framework of which is not stable and such that unambiguously determines the subject of scientific issues. For example, within the framework of public administration science, institutionalism problems were reflected in works of V. H. Bodrov, N. V. Kovalenko, A. F. Kolodii, V. V. Korzhenko, A. O. Kuznetsov, E. M. Kuchmenko, O. Ya. Lazor, V. Yu. Streltsov, and many others. Given the multifaceted manifestation of the connections of public administration with the issues of institutional theory, one should pay attention to the existence of a plurality of possible areas of scientific research, each of 
which is unique and deserves the attention of scholars.

To the issues of the state regulation of innovation activity at the national level, the works of the following domestic scientists are devoted: O. Amosha, V. Heiets, O. Datsii, T. Zhuravlova, L. Lebedieva, O. Melnychenko, P. Sabluk, and others. However, considering the research results of these authors on the management of the innovation process and the identification of innovation potential, it should be noted that they do not adequately cover state measures aimed at achieving the strategic goals of innovative development of the national economy.

\section{The main text}

To explain our study of economic development from the standpoint of the theory of institutionalism, we consider it necessary to present the main factors that have led to the formation of these ideas in a separate direction of scientific thought. According to the team of authors led by Professor V. D. Bazylevych, the historical preconditions for the emergence of institutionalism were linked with: 1) monopolization and corporatization of the economy (transformational shifts in the market system); 2) instability of the market system; 3) aggravation of the problem of employment; 4) increased influence of social organizations; 5) emergence of the need for public control over the market mechanism; 6) aggravation of social contradictions; 7) a gradual loss of the position of the neoclassical doctrine of the self-sufficiency of a competitive market (Bazylevych, Leonenko, Hrazhevska [ta in.], 2005). It is clear that these issues in one form or another have their own manifestation in the modern practice of the functioning of the socio-economic system of society. In our opinion, the above factors can be attributed to the determinants of influence on the process of economic development of the state and its innovative potential.

The first direction. Monopolization of the market of goods and services leads not only to the destruction of market principles of the functioning of the economic system but also to the distortion of the motivation mechanism of the development of business entities: 1) monopolization at the first stage of its development leads to the destruction of the market pricing mechanism, the basis of which is the task of solving the problem of maximizing profits (for example, unjustified from an economic point of view, lowering the price of goods or services (dumping pricing) is aimed at the elimination of competitors); 2) the system of remuneration within the monopoly has a fundamental difference from the system of remuneration in a competitive environment (the monopolist, without having to compete for consumers' preferences, may set wages at a level that is significantly different from the economically justified one. These features of manifestation of the influence of a monopoly on economic development cause its deformation. Such a deformation is manifested through: excess supply of labour; distortion of the mechanism of pricing, including the cost of labour. In addition, the indirect effects of monopoly influence include: under-utilization of the productive potential of society, lowering the pace of the country's socio-economic development; reduction of wages of employees as a result of increased competition in the labour market; increasing tax burden on the employed as a result of the necessary social compensation and support for the unemployed; increase in society's expenditures on retraining unemployed people; exacerbation of the crime situation and the growth of crime; increasing social tension and political instability (Zajchuk, 2006).

In order to demonstrate the extent of possible losses of society (state) only from cyclical unemployment, the indirect source of which may be the process of monopolizing the markets for goods and services, one should mention the dependence that exists between the GDP of the state and cyclical unemployment. The mathematical model of this dependence was substantiated by A. Okun, who proved that the excess of unemployment by $1 \%$ of the minimum sustainable level causes the lagging of the actual GDP volume from the potential by $2.5 \%$ (Okun, 1981).

The second direction. Market system instability determines the lack of clear development prospects both for the socio-economic system as a whole and its components. The comparatively low probability of transformation of the social system according to the elaborated forecasts (development scenarios) leaves a set of options for developing existent potentials. Target development direction of the economy of the country remains uncertain (given the impossibility to determine). One should pay attention to the fact that instability of functioning of the market subsystem of society considerably affects the political stability that, in its turn, is one of the conditions for the development of potentials of a personality (society). Aggravation of political contradictions in social life diverts a large share of resources to solving conflicts and regulating economic relations (Vejmer, 1998).

The third direction. Increasing influence of social organization under certain conditions can influence the economic development of society. For example, one of the methods of activities of labour union organizations is a strike, which depending on its duration can affect the skill level and professional qualities of employees. In this context, one should turn attention to the indirect influence of strikes conducted by trade unions. An illustrative example of such a multiplier is mass protests in Greece in 2010-2011 against tough anti-crisis measures of the national government. According to estimates of economists from the European Commission's expert group, Greece's state budget in 2011 has received over 60 billion euros in taxes only, accounting for about $28 \%$ 
of the country's GDP. One should pay attention to the fact that in countries with a low level of development of civil society, often the governing elite applies the practice of using the workers of certain enterprises (whose leadership is dependent on the authorities) to conduct political actions in support of a certain idea (Afoncev, 2012).

The fourth direction. Solving the issue of social supervision over the market mechanism (public goods, externalities, natural monopolies, and information asymmetry (Zajchuk, 2006) is possible through the state mechanism that, in correcting traditional market failures, exacerbates the problems associated with the power failure (direct democracy, representative power, bureaucratic provision, decentralization). In this context, the system of economic development is under the influence of externalities, which are determined both by market failures and power failures of governance. Determination of directions of correlation for each of them with the social development system requires a separate research, thus we consider it possible only to give some generalizations (Osypova, Vodnik, Klimova [ta in], 2003).

Market failures are traditionally associated with the imperfectness of a competitive model. By this model, participants of market exchange, on the one hand, strive for maximizing utility and, on the other, for maximizing income; moreover, it concerns both to a potential consumer of goods and services and to their producer. An ideal model of such a correlation is Pareto optimal state (impossibility to improve economic status without worsening another one). In this context, a man as a carrier of labour potential is both a producer and a consumer of goods (services) and, accordingly, should achieve the efficiency by Pareto, first of all, within his own personality. This is about, first of all, the correlation between public and private, spiritual and material, social and individual in the process of formation, development, and use of labour potential. For example, to satisfy each level of personal needs, an individual should use the relevant share of own labour opportunities, i.e. carry out a peculiar exchange of the result of the realization of the opportunities to a state of rest as a result of needs' satisfaction. In terms of ideal state (Pareto efficiency), each part of labour potential of an individual should be consistent with the hypothetically usable good (Bazylevych, Leonenko, Hrazhevska, 2005). At the same time, the practice of functioning of market mechanisms testifies the existence of a certain limit both in the use of work opportunities of an individual (the existence of a potential, physiologically available for use) and in the correlation between the potential used and the resulting good. A result of this imbalance can be a condition, at which a person's own labour potential unit, which is additionally used by a person, does not provide satisfaction for the corresponding share of needs. The process of maximizing utility and income sets a conditional limit, at which a person agrees to use the available labour opportunities and a business agrees to compensate (in the form of wages and employment benefits) lost opportunities for the person. There is no doubt that in such conditions, the establishment of Pareto efficiency is impossible, and the process of approaching its status becomes possible only with the participation of society through the use of the state mechanism.

Power failures also have an impact on the process of forming, using, and developing labour potential. There is a situation, in which state power, by increasing the position of a person in the labour market (in the context of finding balances of interest between labour and capital), creates additional burdens on the person himself. For example, each society produces and distributes goods through a combination of individual and collective choices. The majority of individual choices, expressed by participation in markets and other voluntary exchanges, "promote such social values as economic efficiency and freedom. However, some individual choices that appear in situations that we qualify as market failures are departed from public values in predictable ways. The collective choice made by the bodies of government creates at least the opportunity to correct the conscious mistakes of an individual choice. An individual choice is sometimes unable to promote social values in a desirable and predictable way ..." (Vejmer, 1998).

In addition, the establishment of necessary for the functioning of the socio-economic system as a whole bureaucratic procedure by the state creates additional obstacles, to overcome which people are forced to spend their own labour opportunities (for example, the execution of procedures related to the issuance of permits, certificates, reports, etc.). By the way, in the rating of tax systems Paying Taxes 2010, prepared by the World Bank together with Price Waterhouse Coopers, Ukraine took the 181st place out of 183 countries under study. According to the research results, the average Ukrainian enterprise pays for the year 147 taxes and payments, which is the worst indicator in the world (183rd place). As a comparison: in Poland, the number of payments equals to 40, Czech Republic - 12, Belarus - 107, Georgia - 18, the USA - 10, France - 7, China -7 . Most taxes and payments (96) in Ukraine are associated with labour taxation (Pokryshka, Zhalilo, Liapin, 2010). Execution of obligatory tax procedures, such as tax accounting, preparation and submission of reports, payment of taxes, etc., take 736 business hours (175th place) from entrepreneurs annually. As a comparison: in Poland, similar costs are 395 hours, Czech Republic - 613, Georgia - 387, the USA - 187, France - 132, China - 504, Belarus - 900. Given the fact that only $3-5 \%$ of the total population have a bent for entrepreneurial activity, the use of their abilities outside the main activity becomes an unacceptable loss for society (Reva, 2015). 
The fifth direction. A gradual loss of the position of the neoclassical doctrine of the self-sufficiency of a competitive market left a set of unresolved issues. Ideology of market mechanism perfection and selfsufficiency of spontaneous market regulation (the basis of neoclassical direction of the economic theory) has appeared incapable of "studying dual economy characterized by a high level of concentration of production and capitalalong with predominantsmalland medium business sector" (Kniazev, 2010; Bazylevych, Leonenko, Hrazhevska [ta in.], 2005). The difference in views and value orientations of representatives of enterprises, different by the scale of production, and different opportunities of their influence on authorities determined a dislocation of balance in the business environment. New market disproportions (supremacy of the will of representatives of large capital) along with the aggravation of social contradictions create a real threat to the system of labour potential. For example, given the limited organizational resources, organizational structures of small and medium business have considerably fewer opportunities to support their competitiveness. This relates both to the labour productivity itself within the activities of entities of small and medium entrepreneurship (SME) and the system of administration of organizational activity. The situation occurs, at which representatives of SME, when not withstand administrative and tax burdens, are forced to reorganize their own organizational structures and sometimes terminate the business activity. Given the fact that $60.5 \%$ of workplaces in the country account for the very organizational structure of SME that realize $54.4 \%$ of the total production (Petrashevska, Zhadanova, 2012), the issue of their transformation can considerably affect the supply-and-demand situation in the labour market.

\section{Result}

Under the influence of global principal socioeconomic shifts in terms of formation of world information economy, the discussions on issues of the modern economic theory regarding its ability to explain, analyse, and suggest ways to develop a real market economy, became actual. An idea of consensus breaking in the economic theory, which was based on an orthodox Keynes's economic model, is being discussed in the Western literature since the 70 s of the XX century. At the beginning of the 90s of XX century, an American researcher M. Bleaney said that the crisis of economic theory was caused not by its real content but the perception in society, normalization of the situation in the economy restored the reputation of economists and also their self-assurance (Datsij, 2010). The foreign and domestic literature emphasizes that the evolution of economic theory has always been under the influence of various shifts of the real world economy. This is a dialectical process of mutual dependence and influence that contributes to the accumulation and formation of new theoretical knowledge. However, the modern economic reality is so multi-variant and movable that the rate of change is ahead of the pace of its study.

In the message of the President of Ukraine to the Verkhovna Rada of Ukraine "European Choice" it was proclaimed that "stimulation of scientific and technological development, implementation of structural and innovation strategy should become one of the main goals of the Government, the Verkhovna Rada, executive and representative bodies in the field," as well as that "the state can become the direct leader of innovative development, the customer and the organizer of research and development in the most modern areas of scientific and technological advance" (Kontseptsiia naukovo-tekhnichnoho ta innovatsijnoho rozvytku Ukrainy, 2016; Amosha, 2005). At the national level, not only the priority of the innovative development of the national economy but also the place of the state in this process is determined. Therefore, nowadays, innovative and technological development is becoming not only a strategic perspective but also a tactic of state economic policy.

That is, the socio-economic development of the country depends directly on the innovativetechnological potential and on the effectiveness of the state's stimulation of its development at all levels of the national economy.

Thestateregulatestheprocessofinnovativedevelopment through the purposeful influence of the subject of public administration, which represents state power in the form of specially formed bodies and their systems, on the object of management, as a result of which the needs of the state and society in the innovation development are met. The spheres of state activity are directly transformed into the spheres of public administration, such as the development and implementation of state strategies, domestic and foreign policy, legal definition and regulation of relations throughout the society, the formation and implementation of the state budget, etc. (Martynyuk, 2014).

Depending on the scope of managerial measures that are applied at various stages of state regulation, in the economic theory, the following groups of governmentmanagement decisions are distinguished (Melnychenko, 2011; Bakumenko, 2012):

- political government-management decisions. They are implemented in the form of doctrines, concepts, strategies, state programs and projects, the state budget, the formation and reform of the system of state power, state programs and state policy in various spheres of management and public life;

- legal state-management decisions. Public administration is carried out through the constitution, laws, international agreements and treaties, decrees of the President, resolutions of the parliament and 
government, bylaws, orders of heads of central executive bodies, state and industry standards, etc.;

- organizational or administrative governmentmanagement decisions. A form of implementation provisions on central government bodies, orders, directions, minutes of meetings, instructions, and other organizational-subordinate and organizationalcoordination decisions, as well as measures of higher and central bodies of state power.

If we analyse government-management decisions in more detail, taking into account the specifics of innovation-technological development, administrative measures (other than legal regulation) used by the state to manage this sphere of economy, L. Lebedeva (Lebedeva, 2016) distinguishes the following methods of state regulation of innovation processes, and direct methods among them:

- State target programs that provide funding for innovation in the priority sectors of the economy, which is determined by the state;

- Administrative regulation, which provides direct subsidy financing provided in accordance with the current legislation;

- Contract financing - a system of contracts between customers and contractors, where the state acts as a customer and consumer of research and development, and executors - business entities.

Among the measures of indirect influence, the author considers those aimed at stimulating innovation processes and creating a favourable environment for innovation, which is, first and foremost, legal standards that outline the legal framework for active innovation activities and the protection of their intellectual property and information infrastructure.

However, in our opinion, comprehensive state leadership in the results-oriented innovation field should include direct public-management measures: budget financing; targeted state programs; resource support; creation of service infrastructure; government orders (R\&D contracts); creation of scientific and technical zones with a special regime of innovation and investment activity.

Measures of indirect influence should include: tax regulation; subsidy assistance; creation of a legal base aimed at protecting intellectual property rights (copyright); creation of social infrastructure; international cooperation; preferential lending; insurance of investments, etc.

All these measures of public administration are carried out in accordance with the directions specified in the main statutory and legislative documents. First of all, the Concept of Scientific and Technological and Innovative Development of Ukraine, approved by the Verkhovna Rada of Ukraine Resolution in July 1999, determines the priority directions of state support for innovative and technological development (Amosha, 2005; Kontseptsiia naukovo-tekhnichnoho ta innovatsijnoho rozvytku Ukrainy, 2016). They include:
In the field of scientific development: the fundamental science, first of all, developments of domestic scientific groups that have world-wide recognition; applied research and technologies, in which Ukraine has substantial scientific, technological, and production potential and which can ensure the output of domestic products to the world market; higher education, training of scientific and academic personnel on the priority directions of scientific and technological development; development of scientific principles for the development of a socially oriented market economy; scientific provision of the solution to issues of human health and environmental security; system of informational and logistical support of scientific activity;

In the field of technological development: research and creation of conditions for highly productive work and modern life of a person; the development of means for the preservation and protection of human health, the provision of population with medical equipment, drugs, means of prevention and treatment; development of resource and energy-saving technologies; development of modern technologies and equipment for power industry, processing industries, in particular, agroindustrial complex, light and food industry;

In the field of production: the formation of high-tech manufacturing processes, promotion of creation and functioning of innovative structures; the creation of competitive processing facilities; technical and technological updating of basic branches of the economy; the introduction of highly profitable innovation and investment projects, the realization of which can provide the fastest return and launch progressive changes in the structure of production and its development trends.

At the same time, in 2009, the state developed the Strategy of Ukraine's Innovative Development for the years of 2015-2025 in terms of globalization challenges that identifies a number of key areas of activity of public authorities on innovation issues (Androschuk, Zhyliaiev, Chyzhevskyj, Shevchenko, 2015):

1. Provision of financial resources for the implementation of provisions of laws related to innovation and scientific and technological activities, including at the expense of the State Budget of Ukraine for 2015 and subsequent years.

2. Improvement of the structure of public administration in the field of scientific and technical and innovation activities in the direction of clear delimitation and avoidance of duplication of functions of central executive authorities, the introduction of principles of individual responsibility and stability of the system of public administration in this area.

3. Improving the efficiency and expanding the use of state support tools for innovation through mechanisms: provision of grants; direct investment; provision of financial guarantees; stimulating the participation of commercial banks in investing in innovation; provision 
of non-financial services and other types of nonfinancial support; state order for the development of the most important latest technologies in the priority directions of development of science and technology; development of the material and technical base of scientific and scientific-technical activities; insurance of objects of intellectual property rights, comprehensive protection of a fair producer from counterfeit products, anti-competitive actions through a system of economic, legal, organizational measures related to the system of management of industrial property (Androschuk, Zhyliaiev, Chyzhevskyj, Shevchenko, 2015).

4. Working out the issue of tax incentives for business entities that: use a part of their profits to finance costs associated with scientific research and scientific and technical developments; direct their own funds for advanced training and retraining of scientific personnel; provide sponsorship to scientific establishments and higher educational institutions for scientific and scientific-technological activities.

5. The use of measures to determine the possibilities of state support and prospects for organizing production of competitive innovative products of the sixth technological mode (nano-, bio-, informationtelecommunication, and CALS-technologies) in the territory of Ukraine in the following directions: microelectronics; vehicles with hybrid engines; highly efficient agricultural production; computerized medical service; alternative energy sources and energy-saving technologies; intelligent mobile robotics.

6. Promoting the development of information and analytical support for innovative development through: development of the system of state statistical observation in the field of scientific and technical and innovation activity, based on the indicators and standards used in the EU and OECD; development of the system of scientific-technical and patent-license information with the maximum use of possibilities of the Internet; improvement of the system of evaluation of scientific works of the fundamental direction.

7. Implementation of measures for the development of innovation infrastructure in Ukraine: innovative business incubators, innovative development centres, technology transfer centres, and other organizational forms of infrastructure support for innovation, combining science, production, and business, including through state support.

8. Carrying out: modernization of higher education, expansion of autonomy of higher educational institutions in educational, scientific, financial and economic activity; optimization of the network of higher educational institutions; creation of enlarged regional universities, transforming them into powerful scientific and technical, educational and scientificinnovation centres; changes in approaches to the formation of a state order for the training of specialists with higher education, including the training of highly skilled personnel on innovation issues (management, marketing, technology transfer, finance, commercialization); creation of a unified scientific and teaching-methodical mechanism of personnel training for the innovation sphere; state support to young people, who undergo training and probation in leading foreign universities and research centres on innovation activities; improvement of educational and scientific infrastructure and the system of fundamental and applied scientific research in higher educational establishments, implementation of scientific results in the educational process; comprehensive support of scientific and scientific-technical activities concerning further development of science in leading higher educational institutions, updating their material and technical base, in particular, by providing modern highvalue equipment, developing the structure of innovation activity and technology transfer for the implementation of scientific and technical developments (Androschuk, Zhyliaiev, Chyzhevskyj, 2015).

According to the Strategy for the Development of High-Tech Industries by 2025 , developed by the Ministry of Economic Development and Trade of Ukraine in May 2016, there are strategic directions for the modernization of high-tech industries that would contribute to the formation of an innovative economy, increase in technological efficiency, growth of competitiveness, and increase in the efficiency of existing national production:

- preservation and support for intellectual capital;

- provision of financial support for innovation, research and development of high technology;

- introduction of effective institutional mechanisms for the development of high-tech industries;

- creation of modern information and communication infrastructure;

- increase of exports of high-tech products and services; - stimulation of the development of the latest futureoriented and advanced technologies;

- reduction of import dependence of the domestic hightech sector;

- providing a supportive regulatory environment and an independent regulator with appropriate powers;

- creation of economic incentives for the digitization of production.

In addition, the Strategy outlines the main 10 key and perspective sectors and areas of the economy that should become high-tech: the agrarian sector; military-industrial complex; creation of new substances, materials, and nanotechnologies; information and communication technologies; power engineering; hightech construction; development of human sciences, biomedical engineering, cellular medicine, pharmacy; development of transit infrastructure; tourism, recreation, and other directions.

In general, the main areas of public administration declared in different periods are partly repeating and 
complementing one another. Despite the fact that for Ukraine the transformation of the raw material economy into the modern intellectual one is highly relevant, in recent years, there has been no significant progress in the field of the creation and introduction of high technologies in national production.

Describing the main economic indicators of national production according to technological modes (Fig. 1), it can be stated that in 2016 almost $58 \%$ and $38 \%$ of total production of Ukrainian products accounted for branches of respectively the 3rd and 4th technological modes, in particular, ferrous and nonferrous metallurgy, power engineering, universal and precision engineering and instruments industry, electronic engineering industry, inorganic and organic chemistry, polymers, motor transportation, coal and oil consumption, petroleum refining, etc. (Yerokhin, 2006; Dani Derzhavnoi sluzhby statystyky Ukrainy, 2016).

As for capital investments in equipment retrofitting and modernization and investments, their extremely large share ( $83 \%$ and $75 \%$, respectively) falls on these modes. This proves their outdatedness and the need for constant updating and repair. In addition, a significant part of the funds allocated for innovation and scientific development also falls on the 4th technological mode (correspondingly $60.8 \%$ and $69.8 \%$ respectively) but further development of the medium-tech sector will not contribute to the growth of the global competitiveness of the country. To this end, it is necessary to develop sectors of the 5 th and 6 th modes.

Unfortunately, the output of enterprises of the 5th and 6th technological modes accounts for an extremely small share - only $4 \%$ and $0.1 \%$. Also, not much money is invested in scientific and technological and innovative development: the 5 th mode $-23 \%$ in the total amount of financing of R\&D and $8.6 \%$ in the amount of expenses for innovation; the 6 th mode $-0.2 \%$ in both directions. However, this situation leads to an even more lagging economy of the state and its individual sectors or enterprises from the leaders of the world economy, who are already starting to introduce elements of the 7 th technological mode based on cognitive technologies (Data of the State Statistics Service of Ukraine, 2014-2016).

\section{Conclusions}

In accordance with the foregoing, one can formulate the following main conclusions:

1. Generalization of the theoretical direction of the development of institutional theory:

- the system of economic development of society (state) has a plurality of direct and indirect links with the historical background of the emergence and development of the institutional doctrine of economic theory;

- the revealed directions of correlation contribute to the formation of the scientific and methodological basis for further study of economic development and economic potential of a country (state) in the context of the institutional doctrine of economic theory in its relation to the theory of public administration;

- the economic development of a country (state) depends on the institutional environment, in which it operates, and is both an object of its influence and a subject that causes its transformation;

- the revealed relationships allow formulating assumptions about the possibility (necessity) of using tools of institutionalism to study economic development and formation of the economic potential of society (state) within the theory of public administration.

In general, it can be stated that while the economy of Ukraine is not developing in an innovative and

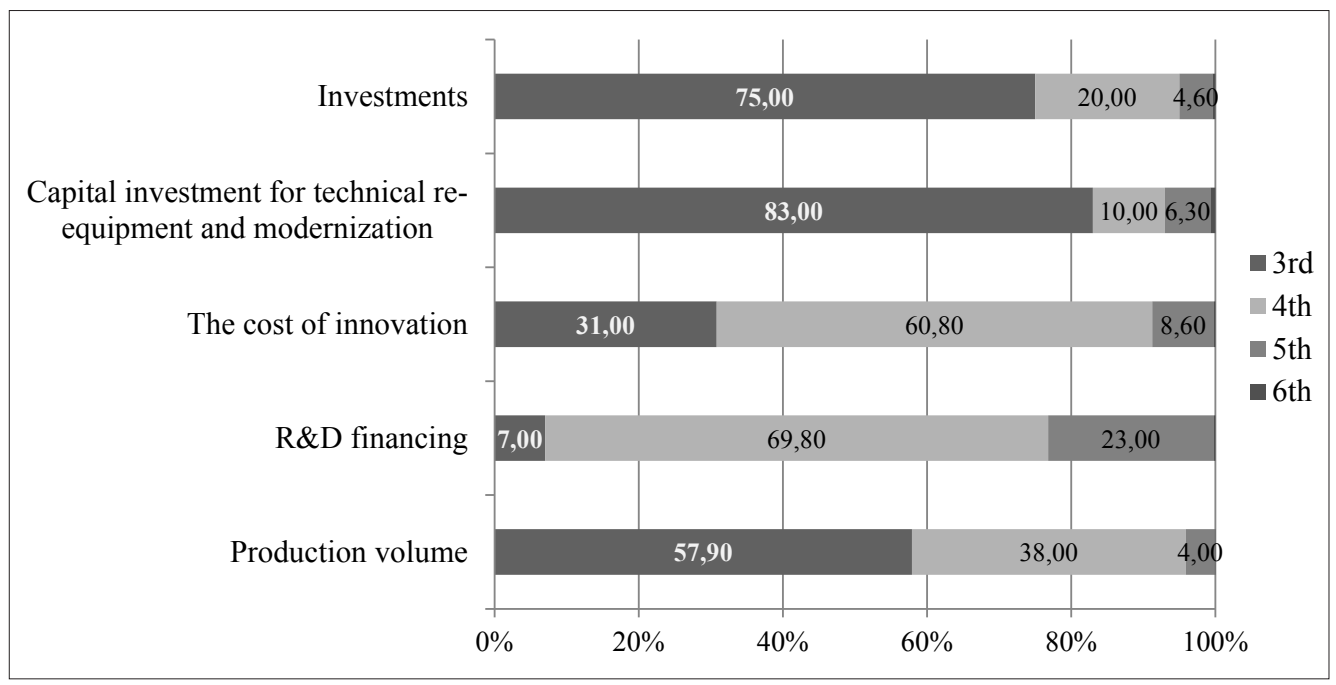

Fig. 1. Tentative distribution of economic indicators depending on technological modes in 2016 Source: calculated by the author (Data of the State Statistics Service of Ukraine, 2014-2016) 
technological way, and the state is trying to develop industries, which are deliberately outdated in terms of technological progress while ignoring high-tech advanced fields of production. In this regard, the state strategy and tactics of development should include support for innovation, aimed at activating the creation and use of the latest high technologies, products, modernization of production processes, management and implementation of advanced innovative products.

\section{References:}

Afoncev S. (2012). Jekonomicheskaja politika i modeli jekonomicheskogo razvitija [Economic policy and models of economic development]. World Economy and International Relations, vol. 4. Pp. 40-47.

Amosha O. I. (2005). Innovatsijnyj shliakh rozvytku Ukrainy: problemy ta rishennia [Innovative Way of Ukraine's Development: Problems and Solutions]. Ekonomist, No 6, Pp. 16-31.

Andriuschenko A. M. (2009). Ekonomichna teoriia: navch. posib. [Economic theory: teaching manual]. Kiev: Tsentr uchb. lit-ry.

Androschuk H. O., Zhyliaiev I. B., Chyzhevskyj B. H., Shevchenko M. M. (2015). Stratehiia innovatsijnoho rozvytku Ukrainy na 2015-2025 roky v umovakh hlobalizatsijnykh vyklykiv [Ukraine's Innovation Development Strategy for 2015-2025 in the context of globalization challenges]. Kiev: Parlamentske vyd-vo.

Bakumenko V. D. (2012). Derzhavno-upravlinski rishennia : Navchalnyj posibnyk [Government-Management Solutions: Tutorial]. Kiev: VPTs AMU.

Bazylevych V. D., Leonenko N. I., Hrazhevska P. M. [ta in.] (2005). Istoriia ekonomichnykh uchen. U 2 ch. Ch. 2 [The history of economic studies. In 2 parts. Part 2]. Kiev: Znannia.

Datsij O. I. (2010). Finansove zabezpechennia innovatsijnoho rozvytku rehionu [Financial support of innovative development of the region]. Naukovyj chasopys - Scientific journal. No12, Pp. 179-180.

Dani Derzhavnoi sluzhby statystyky Ukrainy [Data of the State Statistics Service of Ukraine]. Ofitsijnyj sajt Derzhavnoi sluzhby statystyky Ukrainy - Official site of the State Statistics Service of Ukraine. Retrieved from: http://www.ukrstat.gov.ua.

Kontseptsiia naukovo-tekhnichnoho ta innovatsijnoho rozvytku Ukrainy (2016) [The Concept of Scientific, Technical and Innovative Development of Ukraine]. Holos Ukrainy - Voice of Ukraine. Retrieved from: http://www.golos.com.ua/edition_archive

Kniazev V. M. (2010). Haluz nauky «derzhavne upravlinnia» [Branch of Science "Public Administration"]. Encyclopedic Dictionary of Public Administration. Kiev: NADU.

Lebedeva L. V. (2016). Suchasna innovatsijna polityka derzhavy v Ukraini: problemy ta perspektyvy reformuvannia [Modern Innovation Policy of the State in Ukraine: Problems and Perspectives of Reform] Efektyvna ekonomika (Elektronnyj resurs). vol.1. Retrieved from: /www.economy.nayka.com.ua/?op=1\&z=2664.

Martynyuk O. A. (2014). Derzhavne rehuliuvannia innovatsijnoho mekhanizmu dosiahnennia staloho rozvytku. [State regulation of the innovative mechanism for the achievement of sustainable development] Public Administration: Improvement and Development- Derzhavne upravlinnia: udoskonalennia ta rozvytok. [Electronic resource] No11. Retrieved from: http://www.dy.nayka.com.ua/

Melnychenko O. A. (2011). Innovatsijno-investytsijna model rozvytku natsionalnoi ekonomiky: sotsialnoekonomichni ta derzhavno-upravlinski aspekty [Innovative-investment model of development of the national economy: socio-economic and state-management aspects]. Derzhavne bud-vo. - State building. No 1. Pp. 27-33.

Osypova N. P., Vodnik V. D., Klimova H. P. [ta in]. (2003). Sotsiolohiia: pidruchnyk [Sociology: a textbook]. Kiev: Yurinkom Inter.

Okun A. M. (1981). Prices and Quantities: A macroeconomic analysis / Arthur Melvin Okun. Washington: Brookings Institution Press.

Pokryshka D. S., Zhalilo Ya. A., Liapin D. V. [ta in.] (2010). Mekhanizmy rozvytku pidpryiemnytstva v umovakh postkryzovoho vidnovlennia ekonomiky Ukrainy : analit. Dop [Mechanisms of entrepreneurship development in the post-crisis economic recovery of Ukraine: analyst. Report]. Kiev: NISD.

Petrashevska A. D, Zhadanova Yu. O. (2012). Rehuliuvannia ta pidtrymka innovatsijnoi diialnosti na rivni derzhavy [Regulation and support of innovation at the state level]. Visnyk ONU imeni I.I. Mechnykova - Visnyk ONU named after I.I. Mechnikov, vol. 17, No 3-4. Pp. 22-28.

Reva D. M. (2015). Rol podatkovykh instrumentiv u rehuliuvanni innovatsijnoi aktyvnosti [The role of tax instruments in regulating innovation activity]. Adaptation to the EU law of regulation of the Ukrainian economy in modern condition Kharkiv : NDI PZIR. Pp. 172-177.

Yerokhin S. (2006). Tekhnolohichni uklady, dynamika tsyvilizatsijnykh struktur ta ekonomichna perspektyva Ukrainy [Technological styles, dynamics of civilizational structures and economic prospect of Ukraine]. Retrieved from: http://soskin.info/ea.php?pokazold=20060102\&n=1-2\&y=2006.

Vejmer D. L. (1998). Analiz polityky: Kontseptsii i praktyka [Policy Analysis: Concepts and Practice]. Kiev: Osnovy.

Zajchuk O. V. (2006). Teoriia derzhavy i prava. Akademichnyj kurs : pidruchnyk [Theory of state and law. Academic course: tutorial]. Kiev: Yurinkom Inter. 